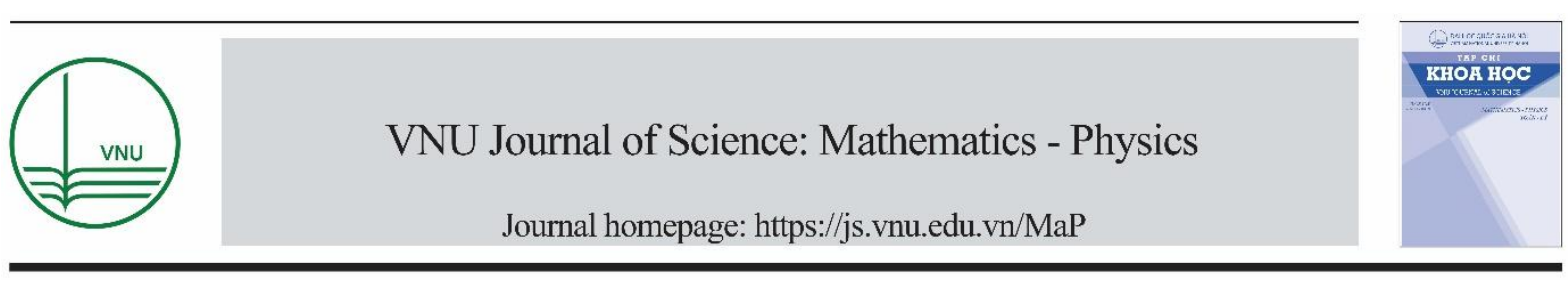

Original Article

\title{
First Principles Study on Electronic and Optical Properties of Quinary Copper-based Sulfides and Selenides $\mathrm{Cu}_{2} \mathrm{HgGe}\left(\mathrm{S}_{1-\mathrm{x}} \mathrm{Se}_{\mathrm{x}}\right)_{4}$
}

\author{
Pham Dinh Khang, Vo Duy Dat, Dang Phuc Toan, Vu Van Tuan* \\ Ton Duc Thang University, 19 Nguyen Huu Tho, Tan Phong, 7 District, Ho Chi Minh City, Vietnam \\ Received 17 May 2020 \\ Revised 02 July 2020; Accepted 15 August 2020
}

\begin{abstract}
Electronic and optical properties of $\mathrm{Cu}_{2} \mathrm{HgGe}\left(\mathrm{S}_{1-x} \mathrm{Se}_{x}\right)_{4}$ compounds $(x=0,0.25,0.5,0.75$, and 1) were revealed by density functional theory (DFT), in which the Heyd-Scuseria-Ernzerhof hybrid functional was used. Dependence of band gap on the Se constituent in $\mathrm{Cu}_{2} \mathrm{HgGe}\left(\mathrm{S}_{1-\mathrm{x}} \mathrm{Se}_{\mathrm{x}}\right)_{4}$ was reported. The substitution of Se element basically cause a slightly lattice expansion and minor change of the band gap. Meanwhile, the overlap of $\mathrm{Cu}$ and $\mathrm{S} / \mathrm{Se}$ states becomes more dense leading to better electron/hole pair separation and inter-band transition of photo-excited electrons. The $\mathrm{Cu}_{2} \mathrm{HgGe}\left(\mathrm{S}_{0.75} \mathrm{Se}_{0.25}\right)_{4}$ compound was predicted to be very promising absorber due to the low band gap, high absorption rate, and low reflectivity in the incoming light energy range from $0 \mathrm{eV}$ to $2 \mathrm{eV}$.

Keywords: $\mathrm{Cu}_{2} \mathrm{HgGe}\left(\mathrm{S}_{1-\mathrm{x}} \mathrm{Se}_{\mathrm{x}}\right)_{4}$, Electronic structures, Optical properties, Semiconductors, DFT calculations.
\end{abstract}

\section{Introduction}

Recently, thin-film solar cells have been widely used in physical devices such as $\mathrm{CuGaSe}_{2}, \mathrm{CuGaSe}_{2}$ and CdTe based absorbers, which can be fabricated at commercial scale [1-3]. Despite the excellent efficiency, these compounds are expensive, which prevents the production of $\mathrm{Cd}$ - or Ga-based absorbers for terawattor petawatt energy sources. The search for earth-abundant elements which is best fit for thinfilm photovoltaic devices results in the discovery of quaternary copper-based sulfides and selenides $\mathrm{Cu}_{2}-$ II-IV-(S/Se $)_{4}$ with outstanding physical properties such as a direct band gap from $1.0 \mathrm{eV}$ to $1.6 \mathrm{eV}$, p-

\footnotetext{
${ }^{*}$ Corresponding author.

Email address: vuvantuan@tdtu.edu.vn
}

https//doi.org/ 10.25073/2588-1124/vnumap.4524 
type electrical conductivity, high absorption rate, and low thermal conductance [4-14]. In the $\mathrm{Cu}_{2}$-II-IV$(\mathrm{S} / \mathrm{Se})_{4}$ compounds, sulfur is not only an abundant but also a multivalent non-metal, while $\mathrm{Ga}, \mathrm{In}, \mathrm{Cd}$, $\mathrm{Cu}$ are the $35^{\text {th }}, 49^{\text {th }}, 48^{\text {th }}$ and $26^{\text {th }}$ most abundant elements in the earths crust [15].

It is well-known that $\mathrm{Cu}_{2} \mathrm{HgGeS}_{4}$, and $\mathrm{Cu}_{2} \mathrm{HgGeSe}_{4}$ crystallize in tetrahedral (space group (SG) $I \overline{4} 2 m$ ) or orthorhombic (SG $P m n 2_{1}$ ) structure, and they are iso-electronic to chalcopyrite $[11,16,17]$, so it is very convenient to apply the same technologies used for chalcopyrite solar cells for these emerging compound including preparation methods, processing, and photovoltaic device design. One of the most important obstacles is that to adjust the band gap to Shockley-Queisser-Efficiency Limit [18], which is $1.3 \mathrm{eV}$ to maximize the efficiency. The band gap of $\mathrm{Cu}_{2} \mathrm{HgGeS}_{4}$ was predicted to be 0.016 $\mathrm{eV}$ by generalized gradient approximation (GGA) calculations performed by Wang et al. [19], meanwhile the obtained results for the band gap of $\mathrm{Cu}_{2} \mathrm{HgGeS}_{4}$ by screened exchange local density approximation (sX-LDA) [20,21] and Heid-Scuseria-Ernzerhof (HSE06) hybrid functionals [22] is 1.27 $\mathrm{eV}$ and $1.21 \mathrm{eV}$, respectively. The band gap of $\mathrm{Cu}_{2} \mathrm{HgGeSe}_{4}$ is $0.54 \mathrm{eV}$ by $\mathrm{HSE} 06$ method, and $1.6 \mathrm{eV}$ by UV-VIS spectroscopy $[22,23]$. It's obviously that the replacement of $\mathrm{S}$ element by Se element causes a decrease of the $\mathrm{Cu}_{2} \mathrm{HgGe}(\mathrm{S} / \mathrm{Se})_{4}$ band gap. In the case of $\mathrm{Cu}_{2} \mathrm{ZnSnSe}_{4}$ and $\mathrm{Cu}_{2} \mathrm{ZnSnS}_{4}$, the band gap is reduced by $0.5 \mathrm{eV}$ [24]. As it is reported previously, the electronic properties of $\mathrm{Cu}_{2}-\mathrm{II}-\mathrm{IV}-(\mathrm{S} / \mathrm{Se})_{4} \mathrm{can}$ be modified by engineering lattice sites, vacancy/impurities doping, and modifying some secondary phases $[4,6,7,10]$. In this paper, the band gap as well as other electronic properties of $\mathrm{Cu}_{2} \mathrm{HgGe}\left(\mathrm{S}_{1-}\right.$ $\left.{ }_{x} \mathrm{Se}_{\mathrm{x}}\right)_{4}$ was for the first time studied by HSE06 method [25]. Despite the fact that HSE06 method usually un- derestimates the band gap of semiconductor, it can give good prediction optical properties $[22,26]$.
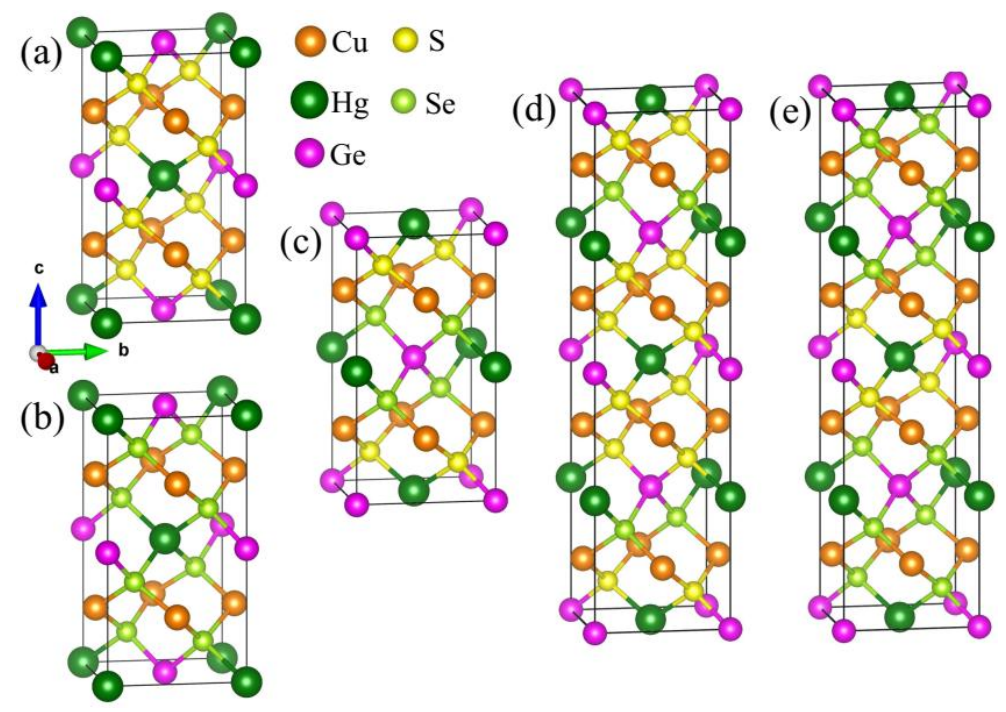

Figure 1. Tetrahedral structures of (a) $\mathrm{Cu}_{2} \mathrm{HgGeS}_{4}$, (b) $\mathrm{Cu}_{2} \mathrm{HgGeSe}_{4}$, (c) $\mathrm{Cu}_{2} \mathrm{HgGe}_{2}\left(\mathrm{~S}_{0.5} \mathrm{Se}_{0.5}\right)_{4}$, (d) $\mathrm{Cu}_{2} \mathrm{HgGe}\left(\mathrm{S}_{0.75} \mathrm{Se}_{0.25}\right)_{4}$ and (e) $\mathrm{Cu}_{2} \mathrm{HgGe}\left(\mathrm{S}_{0.25} \mathrm{Se}_{0.75}\right)_{4}$.

\section{Computational Details}

The $\mathrm{Cu}_{2} \mathrm{HgGe}\left(\mathrm{S}_{1-\mathrm{x}} \mathrm{Se}_{\mathrm{x}}\right)_{4}$ compounds were simulated based on the tetrahedral (space group (SG) $I \overline{4} 2 m)$ using a $(12 \times 12 \times 1) k$-point mesh in the first Brillouin zone. The lattice parameters $a=5.4873 \AA$, and $c=10.5423 \AA$ were taken from experimental data [27]. The projected augmented wave (PAW) method within the framework of Density functional theory (DFT) [28], as employed in the Quantum 
Expresso package [29], was applied for calculation the electronic and optical properties. The exchangecorrelation interaction was modelled by Heyd-Scuseria-Ernzerhof (HSE06) hybrid functional [25], in which the screening $\mu$ and mixing $\alpha$ parameters were 0.20 and 0.25 respectively. The atomic positions in the lattice structure of all $\mathrm{Cu}_{2} \mathrm{HgGe}\left(\mathrm{S}_{1-\mathrm{x}} \mathrm{Se}_{\mathrm{x}}\right)_{4}$ compounds $(x=0,0.25,0.5,0.75$, and 1$)$, as shown in Figure 1, were optimized until the force on each atom was less than $10^{-3} \mathrm{eV} / \AA$ and the difference in total energies became less than $10^{-6} \mathrm{eV}$. The optical properties were calculated based on the matrix values of dielectric function $\varepsilon(\omega)=\varepsilon_{1}(\omega)+i \varepsilon_{2}(\omega)$ as presented in previous studies [30,31]. The real and imaginary parts of the dielectric function were calculated by applying the Kramers-Kronig relations [32].

\section{Results and Discussion}

\subsection{Electronic Properties of $\mathrm{Cu}_{2} \mathrm{HgGe}\left(\mathrm{S}_{1-x} \mathrm{Se}_{x}\right)_{4}$}

The lattice parameters $a$, and $c$ of the optimized $\mathrm{Cu}_{2} \mathrm{HgGeS}_{4}$ are $5.5411 \AA$, and $10.6484 \AA$, respectively. These theoretical results are very close to experimental data which is 5.4873-5.498 $\AA$ for $a$ constant, and 10.5423-10.566 $\AA$ for $c$ constant $[27,33]$. For the $\mathrm{Cu}_{2} \mathrm{HgGeSe}_{4}$ compound, the optimized lattice parameters $a$, and $c$ are $5.5675 \AA$, and $10.6949 \AA$, respectively which are about $3 \%$ lower than the experimental data [34]. Due to the replacement of $\mathrm{S}$ by Se in the $\mathrm{Cu}_{2} \mathrm{HgGeS}_{4}$ compounds, the lattice parameters slightly increase together with the increasing of Se content, which is shown in Figure 2.

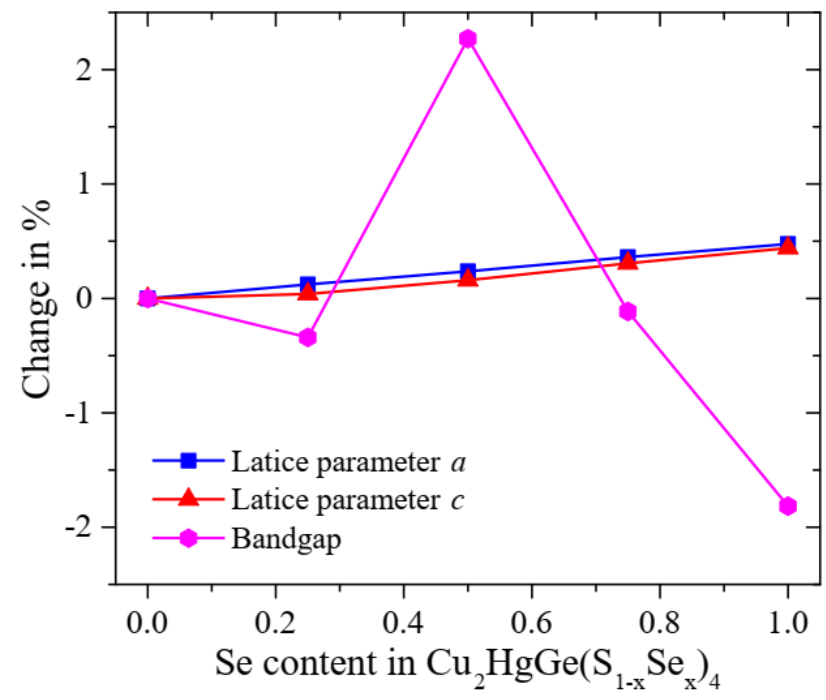

Figure 2. Change in percent of lattice parameter $a$ (blue line), lattice parameter $c$ (red line), and band gap (pink line) corresponding to the $\mathrm{Se}$ content in $\mathrm{Cu}_{2} \mathrm{HgGe}\left(\mathrm{S}_{1-\mathrm{x}} \mathrm{Se}_{\mathrm{x}}\right)_{4}$ compounds.

It can be seen in Figure 2 that during the substitution of Se element, the expansion of the $\mathrm{Cu}_{2} \mathrm{HgGe}\left(\mathrm{S}_{1-\mathrm{x}} \mathrm{Se}_{\mathrm{x}}\right)_{4}$ lattice structure along $a$-axis is a bit larger than along the $c$-axis. However, the $c / a$ ratio always remains 1.92, which is nearly the same experimental ratio for the case of $\mathrm{Cu}_{2} \mathrm{HgGeS}_{4}$, and $\mathrm{Cu}_{2} \mathrm{HgGeSe}_{4}[27,34]$. The calculated band gap by HSE06 method in current study are $0.881 \mathrm{eV}$, and $0.865 \mathrm{eV}$ for $\mathrm{Cu}_{2} \mathrm{HgGeS}_{4}$, and $\mathrm{Cu}_{2} \mathrm{HgGeSe}_{4}$, respectively. These values are slightly different from previous results which are 0.016-1.27 eV, and 0.5-1.6 eV for $\mathrm{Cu}_{2} \mathrm{HgGeS}_{4}$, and $\mathrm{Cu}_{2} \mathrm{HgGeSe}_{4}$, respectively. There is a very large discrepancy in the band gap values observed in previous studies, and the difference in band gap of $\mathrm{Cu}_{2} \mathrm{HgGeS}_{4}$, and $\mathrm{Cu}_{2} \mathrm{HgGeSe}_{4}$ is about $1 \mathrm{eV}$, which is unreasonable large. 
It is necessary to determine the band gap of the two compounds using one method. It is reported that there is an underestimation of semiconductor's band gap by HSE06 method, however the optical properties are predicted accurately. According to our HSE06 calculation, the band gap of $\mathrm{Cu}_{2} \mathrm{HgGeS}_{4}$ is $0.016 \mathrm{eV}$ higher than the one of $\mathrm{Cu}_{2} \mathrm{HgGeSe}_{4}$. As shown in Figure 2, the $\mathrm{Cu}_{2} \mathrm{HgGe}\left(\mathrm{S}_{0.5} \mathrm{Se}_{0.5}\right)_{4}$ compound has the highest band gap, while $\mathrm{Cu}_{2} \mathrm{HgGe}\left(\mathrm{S}_{0.75} \mathrm{Se}_{0.25}\right)_{4}$ compound possesses lowest band gap. In order to study the relation between the $\mathrm{Cu}_{2} \mathrm{HgGe}\left(\mathrm{S}_{1-\mathrm{x}} \mathrm{Se}_{\mathrm{x}}\right)_{4}$ band gap and the content of Se element, the density of states were calculated and presented in Figure 3.
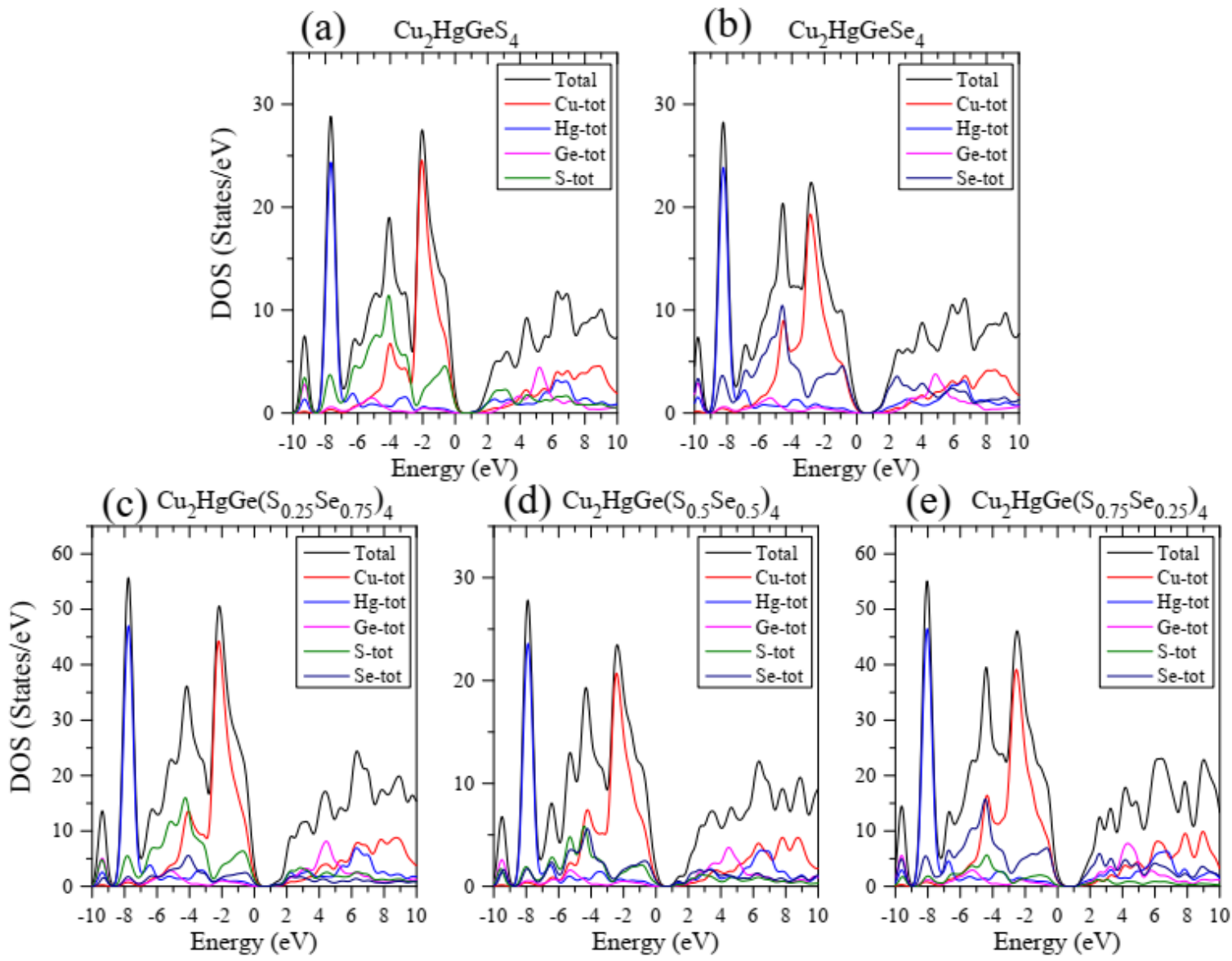

Figure 3. Density of states of $\mathrm{Cu}_{2} \mathrm{HgGe}\left(\mathrm{S}_{1-\mathrm{x}} \mathrm{Se}_{\mathrm{x}}\right)_{4}$ compounds, (a) $x=0$, (b) $x=0.25$, (c) $x=0.5$, (d) $x=0.75$, and (e) $x=1$.

It can be seen in Figure 3 that the valence band of $\mathrm{Cu}_{2} \mathrm{HgGeS}_{4}$ is mostly contributed the states of $\mathrm{Cu}$, and $\mathrm{S}$ atoms. The strong hybridization of these states also indicates the covalent bonding of $\mathrm{Cu}$ and $\mathrm{S}$ atoms, which is favorable for charge carriers transport in such a good solar cell material as $\mathrm{Cu}_{2} \mathrm{HgGeS}_{4}$ [35]. The $\mathrm{Cu}_{2} \mathrm{HgGeSe}_{4}$ exhibits the same valence band, and the $\mathrm{Cu}-\mathrm{Se}$ bonding is also covalent. However, the Se atom causes a higher valence band maximum (VBM) of $\mathrm{Cu}_{2} \mathrm{HgGeSe}_{4}$, while in the conduction band minimum, the Se states are at higher density. This leads to the spreading of states to narrow the band gap. The lower parts in the valence band of both compounds are mainly constructed by $\mathrm{Hg}$, and $\mathrm{S} / \mathrm{Se}$ states. The conduction band is distributed by $\mathrm{Cu}, \mathrm{Hg}, \mathrm{Ge}$, and $\mathrm{S} / \mathrm{Se}$ states. The variation of $\mathrm{Cu}_{2} \mathrm{HgGe}\left(\mathrm{S}_{1-\mathrm{x}} \mathrm{Sex}\right)_{4}$ band structure is shown in Figure 4. 

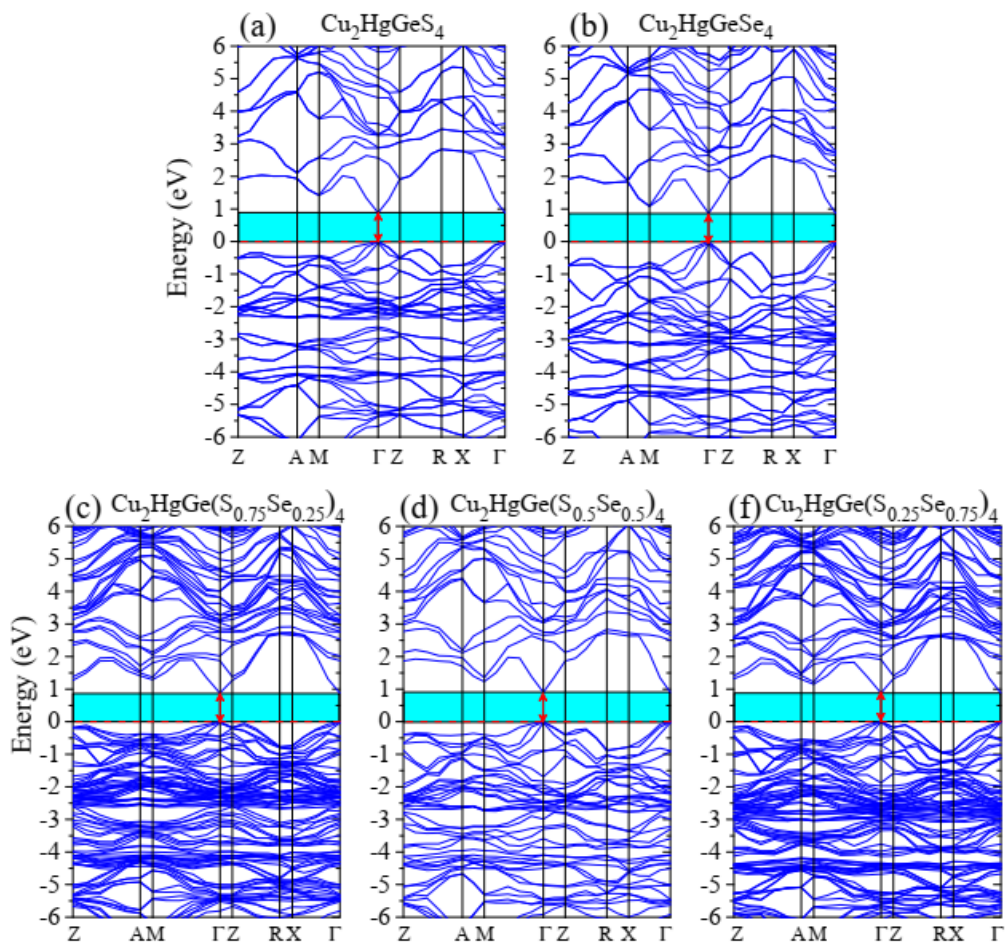

Figure 4. Density of states of $\mathrm{Cu}_{2} \mathrm{HgGe}\left(\mathrm{S}_{1-\mathrm{x}} \mathrm{Se}_{\mathrm{x}}\right)_{4}$ compounds, (a) $x=0$, (b) $x=0.25$, (c) $x=0.5$, (d) $x=0.75$, and (e) $x=1$.

It can be seen that in all compound, both the valence band maximum and the conduction band minimum are located at $\Gamma$-point indicating the direct band gap of $\mathrm{Cu}_{2} \mathrm{HgGe}\left(\mathrm{S}_{1-\mathrm{x}} \mathrm{Se}_{\mathrm{x}}\right)_{4}$. By substituting the Se element, the density of the conduction band increases remarkably. The valence band extrema in the vicinity of -2.5 to $-2 \mathrm{eV}$ are especially dense in the $\mathrm{Cu}_{2} \mathrm{HgGe}\left(\mathrm{S}_{0.75} \mathrm{Se}_{0.25}\right)_{4}$ and $\mathrm{Cu}_{2} \mathrm{HgGe}\left(\mathrm{S}_{0.25} \mathrm{Se}_{0.75}\right)_{4}$ cases. These are the two compounds, whose band gaps are reduced. The dense overlap of $\mathrm{Cu}$ and $\mathrm{S}$ states or $\mathrm{Cu}$ and $\mathrm{Se}$ states in the valence band maximum is favorable of electron/hole separation $[35,36]$ which is very useful for solar cell devices. At deeper energy levels ranging from $-4.5 \mathrm{eV}$ to $4 \mathrm{eV}$ in the valence band, the density of $\mathrm{S} / \mathrm{Se}-\mathrm{Cu}$ hybridization also increases significantly as the content of Se element reaches 0.25 or 0.75 . The $\mathrm{Cu}_{2} \mathrm{HgGe}\left(\mathrm{S}_{0.75} \mathrm{Se}_{0.25}\right)_{4}$ possesses the most dispersive valence band signifying the best inter-band transition of photo-generated electrons in comparison with other $\mathrm{Cu}_{2} \mathrm{HgGe}\left(\mathrm{S}_{1-\mathrm{x}} \mathrm{Se}_{\mathrm{x}}\right)_{4}$ compounds. The inter- band transition of photo-generated electron in $\mathrm{Cu}_{2} \mathrm{HgGe}\left(\mathrm{S}_{1-\mathrm{x}} \mathrm{Se}_{\mathrm{x}}\right)_{4}$ can be studied by analyzing the dielectric function. So, the dielectric function as well as other optical properties of $\mathrm{Cu}_{2} \mathrm{HgGe}\left(\mathrm{S}_{1-\mathrm{x}} \mathrm{Se}_{\mathrm{x}}\right)_{4}$ were calculated and presented in the next paragraph.

\subsection{Optical Properties of $\mathrm{Cu}_{2} \mathrm{HgGe}\left(\mathrm{S}_{1-x} \mathrm{Se}_{x}\right)_{4}$}

As shown in Figure 5(a), the $\varepsilon_{1}(\omega)$ spectrum of $\mathrm{Cu}_{2} \mathrm{HgGe}\left(\mathrm{S}_{1-\mathrm{x}} \mathrm{Se}_{\mathrm{x}}\right)_{4}$ is at high values in the energy range $0-5 \mathrm{eV}$, signifying the high reflectivity of photon within this energy range. For the energy range $7-14 \mathrm{eV}, \varepsilon_{1}(\omega)$ is negative with a concave up at $10.5 \mathrm{eV}$, indicating a damping of electro-magnetic wave. For energy level higher than $15 \mathrm{eV}, \varepsilon_{1}(\omega)$ remains at values near 0 . The static values of $\varepsilon_{1}(0)$ are very different depending on the content of Se element which is in the increasing order $x=0.25<x=0.75<$ $x=0$ or $0.5<x=1$. Figure 5(b) shows the highest imaginary part of the dielectric function at energy range 6-9 eV, and the second highest at 2-3 eV. Studying Figure 3 and Figure 5(b), it can be seen that 
the inter-band transition of excited electrons in $\mathrm{Cu}_{2} \mathrm{HgGe}\left(\mathrm{S}_{1-\mathrm{x}} \mathrm{Se}_{\mathrm{x}}\right)_{4}$ will most likely to happen between the extrema at $-5 \mathrm{eV},-4 \mathrm{eV},-1 \mathrm{eV}$, and $-0.4 \mathrm{eV}$ in the valence band to the conduction band which are related to the extrema at $2 \mathrm{eV}, 3.5 \mathrm{eV}, 5.5 \mathrm{eV}$, and $8 \mathrm{eV}$ in the $\varepsilon_{2}(\omega)$ spectrum. The $\varepsilon_{2}(\omega)$ spectra of different compound show that the more the content of Se element is the higher the inter-band transition becomes. The inter-band transition also depends on the light absorption of the compounds which is calculated and shown in Figure 6(a).
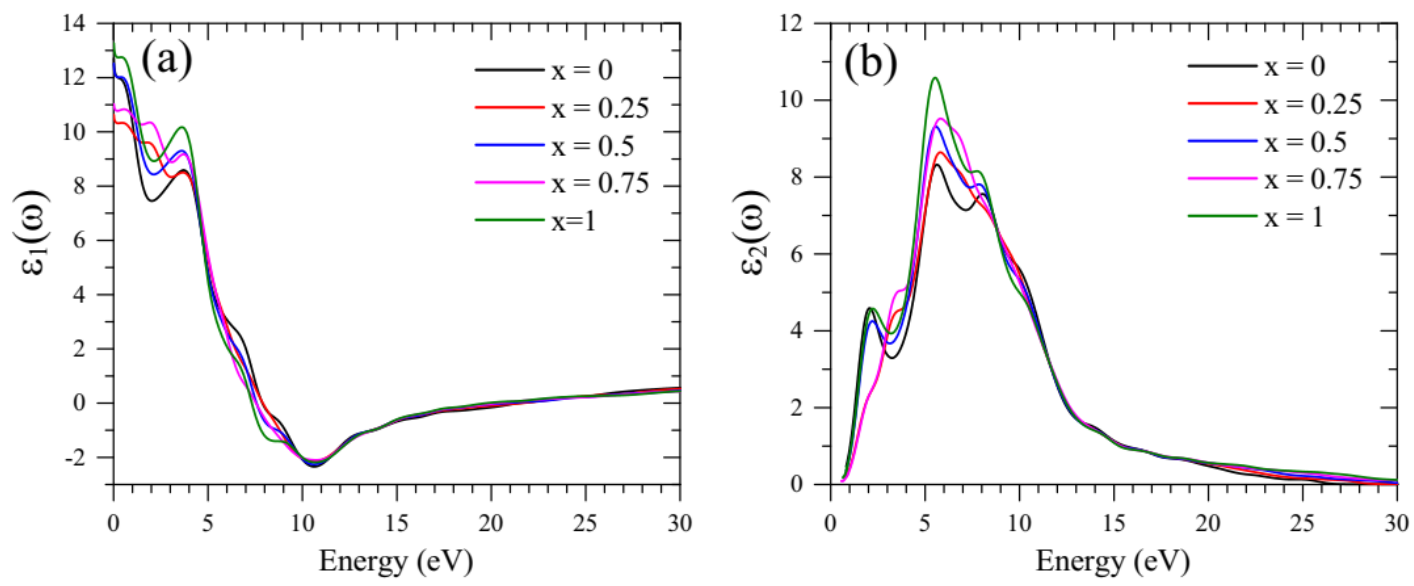

Figure 5. (a) Real and (b) imaginary parts of dielectric function of $\mathrm{Cu}_{2} \mathrm{HgGe}\left(\mathrm{S}_{1-\mathrm{x}} \mathrm{Se}_{\mathrm{x}}\right)_{4}$ compounds.
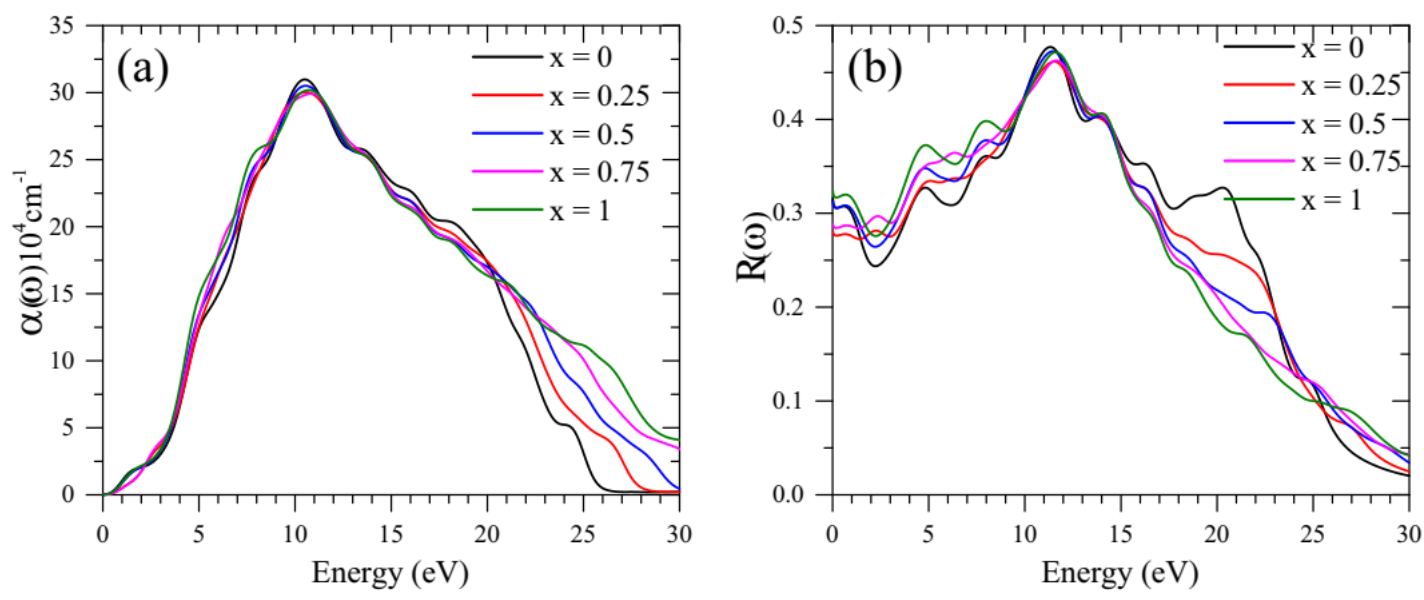

Figure 6. (a) Absorption rate and (b) reflectivity of $\mathrm{Cu}_{2} \mathrm{HgGe}\left(\mathrm{S}_{1-\mathrm{x}} \mathrm{Se}_{\mathrm{x}}\right)_{4}$ compounds.

From Figure 6(a), it can be seen that $\mathrm{Cu}_{2} \mathrm{HgGe}\left(\mathrm{S}_{1-\mathrm{x}} \mathrm{Se}_{\mathrm{x}}\right)_{4}$ possesses an amaz- ing absorption range which includes infrared and ultra-violet spectra. The most intense absorption is at energy range 7-18 eV with absorption rate at the order of magnitude $10^{5} \mathrm{~cm}^{-1}$. However, attention must be paid to the energy range 1-4 eV, which corresponds to infraredvisible light, as this range contain the most energy from the sun. In this range, the $\mathrm{Cu}_{2} \mathrm{HgGe}\left(\mathrm{S}_{0.75} \mathrm{Se}_{0.25}\right)_{4}$ compound again shows its advantageous property as it is in the group of higher absorption rate. Moreover, the reflectivity of $\mathrm{Cu}_{2} \mathrm{HgGe}\left(\mathrm{S}_{0.75} \mathrm{Se}_{0.25}\right)_{4}$ is amazingly the lowest in the energy range $0-2 \mathrm{eV}$, Figure $6(\mathrm{~b})$, and it continues to the second lowest for higher energy level. Generally, the reflectivity of $\mathrm{Cu}_{2} \mathrm{HgGe}\left(\mathrm{S}_{1-\mathrm{x}} \mathrm{Se}_{\mathrm{x}}\right)_{4}$ is about 0.3 in the infra to visible ranges, and it may reach $0.4-0.5$ at ultra-violet range. 


\section{Conclusion}

The effect of the Se content on the electronic and optical properties of $\mathrm{Cu}_{2} \mathrm{HgGe}\left(\mathrm{S}_{1-\mathrm{x}} \mathrm{Se}_{\mathrm{x}}\right)_{4}$ compounds was studied performing DFT calculation using the Heyd-Scuseria-Ernzerhof hybrid functional (HSE06). The substitution of Se element causes slight asymmetric expansion of lattice parameters. At the same time, the band gaps of $\mathrm{Cu}_{2} \mathrm{HgGe}\left(\mathrm{S}_{1-\mathrm{x}} \mathrm{Se}_{\mathrm{x}}\right)_{4}$ tends to decrease with the increasing of $\mathrm{Se}$ content, except for $\mathrm{Cu}_{2} \mathrm{HgGe}\left(\mathrm{S}_{0.5} \mathrm{Se}_{0.5}\right)_{4}$ compound with largest band gap of $0.901 \mathrm{eV}$. The band gap is mainly determined by hybridization of $\mathrm{Cu}$ and $\mathrm{S}$ states in the valence band maximum and the admixture of $\mathrm{Cu}, \mathrm{Hg}, \mathrm{Ge}$, and $\mathrm{S} / \mathrm{Se}$ states in the conduction band minimum. The two compounds $\mathrm{Cu}_{2} \mathrm{HgGe}\left(\mathrm{S}_{0.75} \mathrm{Se}_{0.25}\right)_{4}$ and $\mathrm{Cu}_{2} \mathrm{HgGe}\left(\mathrm{S}_{0.25} \mathrm{Se}_{0.75}\right)_{4}$ exhibit very dense overlap of $\mathrm{Cu}$ and $\mathrm{S} / \mathrm{Se}$ states which is favorable for electron/hole separation. The strong hybridization also indicates covalent bond nature of $\mathrm{Cu}-\mathrm{S} / \mathrm{Se}$ resulting in better charge carrier transport.

In general, the $\mathrm{Cu}_{2} \mathrm{HgGe}\left(\mathrm{S}_{1-\mathrm{x}} \mathrm{Se}_{\mathrm{x}}\right)_{4}$ compounds possess high reflectivity at $0-5 \mathrm{eV}$, and the damping of electro-magnetic occurs at 7-14 eV. The extrema at $2 \mathrm{eV}, 3.5 \mathrm{eV}, 5.5 \mathrm{eV}$, and $8 \mathrm{eV}$ in the $\varepsilon_{2}(\omega)$ spectrum are related to high inter-band transitions of photo-excited electrons from extrema at $-5 \mathrm{eV}$, $-4 \mathrm{eV},-1 \mathrm{eV}$, and $-0.4 \mathrm{eV}$ in the valence band to the conduction band. The $\mathrm{Cu}_{2} \mathrm{HgGe}\left(\mathrm{S}_{0.75} \mathrm{Se}_{0.25}\right)_{4}$ compound was predicted to be the most advantageous absorber among $\mathrm{Cu}_{2} \mathrm{HgGe}\left(\mathrm{S}_{0.5} \mathrm{Se}_{0.5}\right)_{4}$ compounds as it possesses lowest band gap of $0.878 \mathrm{eV}$, one of the highest absorp- tion rate and lowest reflectivity in the energy range $0-2 \mathrm{eV}$.

\section{Acknowledgments}

This research is funded by the Vietnam National Foundation for Science and Technology Development (NAFOSTED) under Grant Number 103.01-2018.334.

\section{References}

[1] R. Chandran, S.K. Panda, A. Mallik, A short review on the advancements in electroplating of CuInGaSe $\mathrm{C}_{2}$ thin films, Materials for Renewable and Sustainable Energy 7 (2018) 6. https://doi.org/10.1007/s40243-018-0112-1.

[2] S.G. Kumar, K.S.R.K. Rao, Physics and chemistry of CdTe/CdS thin film heterojunction photovoltaic devices: fundamental and critical aspects, Energy \& Environmental Science 7 (2014) 45-102. https://doi.org/10.1039/C3EE41981A.

[3] Optical Thin Films and Coatings 2nd Edition: From Materials to Applications, Piegari, F. Flory Ed., Woodhead Publishing, 2018.

[4] Y. Dong, H. Wang, G.S. Nolas, Synthesis and thermoelectric properties of $\mathrm{Cu}$ excess $\mathrm{Cu}_{2} \mathrm{ZnSnSe}_{4}$, Physica Status Solidi (RRL) Rapid Research Letters 8 (2014) 61-64. https://doi.org/10.1002/pssr.201308274.

[5] Y. Dong, L. Wojtas, J. Martin, G.S. Nolas, Synthesis, crystal structure, and transport properties of quaternary tetrahedral chalcogenides, Journal of Materials Chemistry C 3 (2015) 10436-10441. https://doi.org/10.1039/C5TC01606A.

[6] T. Gershon, K. Sardashti, Y.S. Lee, O. Gunawan, S. Singh, D. Bishop, A.C. Kummel, R. Haight, Compositional effects in $\mathrm{Ag}_{2} \mathrm{ZnSnSe}_{4}$ thin films and photovoltaic devices, Acta Materialia 126 (2017) 383-388. https://doi.org/10.1016/j.actamat.2017.01.003.

[7] H. Guo, C. Ma, K. Zhang, X. Jia, Y. Li, N. Yuan, J. Ding, The fabrication of Cd-free $\mathrm{Cu}_{2} \mathrm{ZnSnS}_{4}-\mathrm{Ag}_{2} \mathrm{ZnSnS}_{4}$ heterojunction photovoltaic devices, Solar Energy Materials and Solar Cells 178 (2018) 146-153. https://doi.org/10.1016/j.solmat.2018.01.022.

[8] E. Hajdeu-Chicarosh, E. Lhderanta, M. Guc, K. Lisunov, M. Shakhov, I. Zakharchuk, Levcenko, E. Arushanov, High-field magnetotransport in $\mathrm{Cu}_{2} \mathrm{ZnGeS}_{4}$ single crystals, Solar Energy 172 (2018) 184-190. https://doi.org/10.1016/j.solener.2018.04.043. 
[9] C.P. Heinrich, T.W. Day, W. G. Zeier, G.J. Snyder, W. Tremel, Effect of isovalent substitution on the thermoelectric properties of the $\mathrm{Cu}_{2} \mathrm{ZnGeSe}_{4-\mathrm{x}} \mathrm{S}_{\mathrm{x}}$ series of solid solutions, Journal of the American Chemical Society 136 (1) (2014) 442-448. https://doi.org/10.1021/ja410753k.

[10] J. Henry, K. Mohanraj, G. Sivakumar, Photoelectrochemical cell performances of $\mathrm{Cu}_{2} \mathrm{ZnSnSe}_{4}$ thin films deposited on various conductive substrates, Vacuum 156 (2018) 172-180. https://doi.org/10.1016/j.vacuum.2018.07. 031.

[11] A.A. Lavrentyev, B.V. Gabrelian, V.T. Vu, P.N. Shkumat, V.A. Ocheretova, O.V. Parasyuk, O.Y. Khyzhun, Electronic structure and optical properties of $\mathrm{Cu}_{2} \mathrm{CdGeS}_{4}$ : DFT calculations and $\mathrm{X}$-ray spectroscopy measurements, Optical Materials 47 (2015) 435-444. https://doi.org/10.1016/j.optmat.2015.06.017.

[12] T.K. Todorov, J. Tang, S. Bag, O. Gunawan, T. Gokmen, Y. Zhu, D.B. Mitzi, Beyond 11\% efficiency: Characteristics of state-of-the-art $\mathrm{Cu}_{2} \mathrm{ZnSn}(\mathrm{S}, \mathrm{Se})_{4}$ solar cells, Advanced Energy Materials 3 (2013) 34-38. https://doi.org/10.1002/aenm.201200348.

[13] M. Valdés, A. Hernndez-Martinez, Y. Sánchez, F. Oliva, V. Izquierdo-Roca, A. Perez Rodriguez, E. Saucedo, $\mathrm{Cu}_{2} \mathrm{ZnSnSe}{ }_{4}$ based solar cells combining coelectrodeposition and rapid thermal processing, Solar Energy 173 (2018) 955-963. https://doi.org/10.1016/j.solener.2018.08.049.

[14] T.V. Vu, A.A. Lavrentyev, B.V. Gabrelian, K.D. Pham, C.V. Nguyen, K.C. Tran, H.L. Luong, M. Batouche, O.V. Parasyuk, O.Y. Khyzhun, Electronic, optical and elastic properties of $\mathrm{Cu}_{2} \mathrm{CdGeSe}_{4}$ : A first-principles study, Journal of Electronic Materials 48 (2019) 705-715. https://doi.org/10.1007/s11664-018-6781-9.

[15] Abundance of Elements in the Earth's Crust and in the Sea, 97 ${ }^{\text {th }}$ Edition, CRC Handbook Of Chemistry And Physics, 2016-2017, pp. 14-17.

[16] T. Hirai, K. Kurata, Y. Takeda, Derivation of new semiconducting compounds by cross substitution for group IV semiconductors, and their semiconducting and thermal properties, Solid-State Electronics 10 (1967) 975-981. https://doi.org/10.1016/0038-1101(67)90146-3.

[17] A.V. Stanchik, V.F. Gremenok, R. Juskenas, I.I. Tyukhov, M.S. Tivanov, C. Fettkenhauer, V.V. Shvartsman, R. Giraitis, U. Hagemann, D.C. Lupascu, Effects of selenization time and temperature on the growth of $\mathrm{Cu}_{2} \mathrm{ZnSnSe}_{4}$ thin films on a metal substrate for flexible solar cells, Solar Energy 178 (2019) 142-149. https://doi.org/10.1016/j.solener.2018.12.025.

[18] S. Rühle, Tabulated values of the shockleyqueisser limit for single junction solar cells, Solar Energy 130 (2016) 139-147. https://doi.org/10.1016/j.solener.2016.02.015.

[19] Y.J. Wang, H. Lin, T. Das, M.Z. Hasan, A. Bansil, Topological insulators in the quaternary chalcogenide compounds and ternary famatinite compounds, New Journal of Physics 13 (2011) 085017. https://doi.org/10.1088/1367-2630/13/8/085017.

[20] D.M. Bylander, L. Kleinman, Good semiconductor band gaps with a modified local-density approximation, Physical Review B 41 (1990) 7868-7871. https://doi.org/10.1103/PhysRevB.41.7868.

[21] R. Chetty, A. Bali, R.C. Mallik, Thermoelectric properties of indium doped $\mathrm{Cu}_{2} \mathrm{CdSnSe}_{4}$, Intermetallics 72 (2016) 17-24. https://doi.org/10. 1016/j.intermet.2016.01.004.

[22] N. Sarmadian, R. Saniz, B. Partoens, D. Lamoen, First-principles study of the optoelectronic properties and photovoltaic absorber layer efficiency of Cu-based chalcogenides, Journal of Applied Physics 120 (2016) 085707. https://doi.org/10.1063/1.4961562.

[23] W. Li, M. Ibáez, D. Cadavid, R.R. Zamani, J. Rubio-Garcia, S. Gorsse, J.R. Morante, J. Arbiol, A. Cabot, Colloidal synthesis and functional properties of quaternary Cu-based semiconductors: $\mathrm{Cu}_{2} \mathrm{HgGeSe}_{4}$, Journal of Nanoparticle Research 16 (2014) 2297. https://doi.org/10.1007/s11051-014-2297-2.

[24] S. Botti, D. Kammerlander, M.A.L. Marques, Band structures of $\mathrm{Cu}_{2} \mathrm{ZnSnS}_{4}$ and $\mathrm{Cu}_{2} \mathrm{ZnSnSe}_{4}$ from many-body methods, Applied Physics Letters 98 (2011) 241915. https://doi.org/10.1063/1.3600060.

[25] J. Heyd, G.E. Scuseria, M. Ernzerhof, Hybrid functionals based on a screened coulomb potential, The Journal of Chemical Physics 118 (2003) 8207-8215. https://doi.org/10.1063/1.1564060.

[26] H. Zhao, C. Persson, Optical properties of $\mathrm{Cu}(\mathrm{In}, \mathrm{Ga}) \mathrm{Se}_{2}$ and $\mathrm{Cu}_{2} \mathrm{ZnSn}(\mathrm{S}, \mathrm{Se})_{4}$, Thin Solid Films 519 (2011) 75087512. https://doi.org/10.1016/j.tsf.2010.12.217.

[27] O.V. Parasyuk, L.D. Gulay, Y.E. Romanyuk, I.D. Olekseyuk, Phase diagram of the quasi-binary $\mathrm{Cu}_{2} \mathrm{GeS}_{3}-\mathrm{HgS}$ system and crystal structure of the $\mathrm{Li}$-modification of the $\mathrm{Cu}_{2} \mathrm{HgGeS}_{4}$ compound, Journal of Alloys and Compounds 334 (2002) 143-146. https://doi.org/10.1016/S0925-8388(01)01746-7. 
[28] P.E. Blöchl, Projector augmented-wave method, Physical Review B 50 (1994) 17953-17979. https://doi.org/10.1103/PhysRevB.50.17953.

[29] P. Giannozzi, S. Baroni, N. Bonini, M. Calandra, R. Car, C. Cavazzoni, D. Ceresoli, G. L. Chiarotti, M. Cococcioni, I. Dabo, A. Dal Corso, S. de Gironcoli, S. Fabris, G. Fratesi, R. Gebauer, U. Gerstmann, C. Gougoussis, A. Kokalj, M. Lazzeri, L. Martin-Samos, N. Marzari, F. Mauri, R. Mazzarello, S. Paolini, A. Pasquarello, L. Paulatto, C. Sbraccia, S. Scandolo, G. Sclauzero, A.P. Seitsonen, A. Smogunov, P. Umari, R.M. Wentzcovitch, Quantum espresso:a modular and open-source software project for quantum simulations of materials, Journal of Physics: Condensed Matter 21 (2009) 395502. https://doi.org/10.1088/0953-8984/21/39/395502.

[30] T.V. Vu, A.A. Lavrentyev, B.V. Gabrelian, V.A. Ocheretova, O.V. Parasyuk, O.Y. Khyzhun, Particular features of the electronic structure and optical properties of $\mathrm{Ag}_{2} \mathrm{PbGeS}_{4}$ as evidenced from first-principles DFT calculations and XPS studies, Materials Chemistry and Physics 208 (2018) 268-280. https://doi.org/10.1016/j.matchemphys.2018.01.042.

[31] T.V. Vu, A.A. Lavrentyev, B.V. Gabrelian, O.V. Parasyuk, V.A. Ocheretova, O.Y. Khyzhun, Electronic structure and optical properties of $\mathrm{Ag}_{2} \mathrm{HgSnSe}_{4}$ : First- principles DFT calculations and X-ray spectroscopy studies, Journal of Alloys and Compounds 732 (2018) 372-384. https://doi.org/10.1016/j.jallcom.2017.10.198.

[32] C. Ambrosch-Draxl, J.O. Sofo, Linear optical properties of solids within the full-potential linearized augmented planewave method, Computer Physics Communications $175 \quad$ (2006) $1-14$. https://doi.org/10.1016/j.cpc.2006.03.005.

[33] W. Schfer, R. Nitsche, Tetrahedral quaternary chalcogenides of the type $\mathrm{Cu}_{2}-\mathrm{II}-\mathrm{V}-\mathrm{S}_{4}\left(\mathrm{Se}_{4}\right)$, Materials Research Bulletin 9 (1974) 645-654. https://doi.org/10.1016/0025-5408(74)90135-4.

[34] Copper Zinc Tin Sulfide-Based Thin-Film Solar Cells, K. Ito Edition, John Wiley \& Sons, Ltd. https://doi.org/10.1002/9781118437865.

[35] F. Wu, H. Song, J. Jia, X. Hu, Effects of Ce, Y, and Sm doping on the thermoelectric properties of $\mathrm{Bi}_{2} \mathrm{Te}_{3}$ alloy, Progress in Natural Science: Materials International 23 (2013) 408-412. https://doi.org/10.1016/j.pnsc.2013.06.007.

[36] X. Fan, L. Zang, M. Zhang, H. Qiu, Z. Wang, J. Yin, H. Jia, S. Pan, C. Wang, A bulk boron-based photocatalyst for efficient dechlorination: $\mathrm{K}_{3} \mathrm{~B}_{6} \mathrm{O}_{10} \mathrm{Br}$, Chemistry of Materials $26 \quad$ (2014) 3169-3174. https://doi.org/10.1021/cm500597e. 